\title{
Educational Perspective Based on the Epistemological Foundations of Sadra-ee Philosophy
}

\author{
Alireza Shavakhi ${ }^{1, *}$, Bakhtiar Nasrabadi Hasan Ali $^{1}$, Mirshah Ja'fari Sayeid
}

Ebrahim $^{1}$, Beheshti Sa'eed ${ }^{2} \&$ Shahnazari Ja' far $^{3}$

${ }^{1}$ Faculty of Educational Sciences and Psychology, University of Isfahan, Isfahan, Iran
${ }^{2}$ Faculty of Educational Sciences and Psychology, Tabatabaii University, Tehran, Iran
${ }^{3}$ Faculty of Humanities Sciences, University of Isfahan, Isfahan, Iran
${ }^{*}$ Corresponding author: Faculty of Educational Sciences and Psychology, University of Isfahan,
Isfahan, Iran

Tel: 98-311-793-2543Ｅ-mail: Shavakhi2007@gmail.com

Received: September 9, 2012 Accepted: October 25, 2012 Published: January 13, 2013

doi:10.5296/ije.v5i1.2354 URL: http://dx.doi.org/10.5296/ije.v5i1.2354

\begin{abstract}
This research aims at analyzing the epistemological foundations of Sadra-ee wisdom, justifying educational elements based on that foundations and providing an educational perspective based on that. The research method has been philosophical analysis with a synthetic approach. To achieve the research objectives, first, Sadra's epistemological foundations from numerous works of Mulla Sadra and some of his exponents are analyzed, then educational elements based on that foundations are justified; Sadra's fundamental epistemological foundations in two areas of ontology and epistemology include: 1) to become identical knowledge with being , 2) self-speech is the wholly of faculties, 3) the unity of the knower, known and the act of knowing, 4) priority of theoretical reason over practical one, 5) Establishment of the balance between the tangible and intelligible worlds, and 6) hierarchy of knowledge. Important educational elements i.e. objective, curriculum, teacher, student, and teaching methods have been analyzed with regard to the above-mentioned foundations and it has been indicated that the educational elements in this view have particular features and characteristics which can lead the learner to self-actualization and manifest rays of rationality i.e. faith in him. Educational perspective resulting from such a foundation emphasizes on the reality of education that in this case, education at the time of unity and preserving uniqueness like truth of being includes multiples such as strength and weaknesses, priority and posteriority, perfection and imperfection. The other result of this study states that an equilibrium must be established among the educational elements of this perspective; this balance is established in both any level of knowledge and also in longitudinal levels of knowledge.
\end{abstract}

Keywords: primacy of being; substantial motion; epistemology; Educational perspective; Education truth 


\section{Introduction}

The important task of the divine religions, is to remove deviant thoughts from human mind and to water its empty place with the natural laws and regulations of the created world. In other words, their mission is educating human and guiding him to his original position i.e. divine successor; attention to God is the axis of all Islamic beliefs and also its educational method. So, all programs and guidances should be towards it and a human life follows based on that, thus, Islam is in preparing and making a decent human and not a decent citizen (Ghotb, quoted by Jafari , 1973, p.10), human having hidden properties and pearls within himself. On the other hand, the requirement of divine wisdom is to create a perfect society including various creatures and among the creatures of this perfect society is human who have various components and gestures and will obtain perfection in terms of any power that has adopted; In such a society, the man is placed in a rank that can achieve the position of perfect man through education, that is, the creation and survival cause of the world is the perfect man forever and from the beginning of the world to the hereafter, (Nasri, 1992,pp. 303-5).

Sadra-ee wisdom as a thought system by a theologian links the proof, mystic and Qur'anic foundations to each other and has such a consistency and configuration that can guide human toward knowing human reality and finally real happiness and prosperity. In transcendental wisdom, while at the time of creation, the man is as a oneness essence, at the end of an issue, he is not considered as a united truth; Mulla Sadra's based on his own theosophia thoughts and reflections on the Quran verses concluded that regarding the end of an issue, humans are divided into three groups of companions of the left, companions of the right, and those who approach to God as much as possible (Ebrahimi Dinani, 2006, vol.3, p. 69) and he knew this division according to the essence and truth and mentioned that each group consists of various species. The basis of this speech in its educational aspect is that in doing an issue, the humans are not placed under one kind according to acquainting their inward gods and will not enjoy a unit truth; Mulla Sadra's emphasis on human, start and end and also the way from start to end indicates the special status of human and learning wisdom in his point of view (Akbarian, 2010; Nasri, 2006) and specifies that the education and educatability of human have major importance in transcendental wisdom and the end of accumulation of wisdom is human perfectionity in both practical and theoretical reasons, which in turn is possible through education.

The present study tries to investigate, analyze and extract the continuous and coherent relationship between the concepts and foundations of epistemology of transcendental wisdom and the educational elements in it, then to compile them to provide the educational perspective. In other words, by this method, the foundations of the epistemological Transcendental wisdom is analyzed in separation and then relation among them and with the whole is considered in order to determine the dimensions of their relationships (Sajjadi, 1997, p. 106), and in the next stage, their educational elements are determined and justified based on the epistemology foundations, then they are offered in one perspective. 


\section{Fundamental Principles and Basic Rules of Transcendental Wisdom}

The primacy of being and substance motion are two basic and fundamental principles of Transcendental Wisdom that all philosophy issues such as ontology, epistemology, and anthropology find consistency and stability based on them. According to these two principles, the primacy of being, existence is something which itself has existed outside and the realization of objects and creatures depend on it, thus Mulla Sadra (1571-1640) differentiates between the concept of being and its truth. In other words, according to the principle of existence, the concept of an object is not different because it is a unit concept, and perfection and defect is not realizable in the meaning of an object (Mulla Sadra, 2007, pp. 147-207). But, this principle has important supplies and consequences like any other philosophical principle that among these consequences the unity of being, the gradation and the possible of needness can be mentioned (Ebrahimi Dinani, 2009 a, p. 289; Ebrahimi Dinani, 2006, vol 3, p. 22; Izutsu, 1980; Khamenei, 2004 , pp. 89-91).

The unity of all being has always been basically and fundamentally discussed among Islamic scholars and wises and put it simple, it is considered as how a truth can appear in the form of multiples affairs and reveal its face while preserves its unity. The appearance of the issue of oneness and gradation in the works of the Islamic scholars and wises refers to the logic particular and general discussion and division of general to gradiation and univocal. The univocal is a concept that applies on hard affairs same and ambiguous is a concept that does not apply on same instances (Meshkat Al-Dini, 1360, p. 47; Hakkak, 2006, p. 29).

In Transcendental Wisdom gradiation in an object takes place when there is priority and posteriority, or a kind of weakness and strength or defect and perfection between its examples; thus, the criterion of gradation is that a reality actualizes such that what causes the difference in its examples return into what is shared in common among them and what is shared in common in its examples return into what causes their difference (Sabzevari, 2008, pp. 165-9). Therefore, unity in plurality and plurality in unity becomes justifiable.

Other rule and consequence from the primacy of being is the needness possibility also called the being possibility. Based on the primacy of being, Mulla Sadra categorizes the existence into three types: a) the being of existence is for itself and substantive one (self existent) which is also called soul being or predicate being, $b$ ) the being of existence is for other objects such as the existence of descriptions and accidents, and c) the existence which is found in the relation of and in the proportion of the objection and the predicate, and has no independence by itself (Khamenie, 2004, pp. 89-91). By such categorization Mulla Sadra believes that ascribing the being to the quiddity is metaphorical and the quiddity is not a portion of the being, to be defined by the possible being, so the possible existences are not the primarily existence, but even are not also the secondarily existence and are only the presentation of being, and this is the very meaning of being possibility or the needness possibility, thus all the possibilities and existences are the very needness, that is, both in creation and in survival they need the causation (Izutsu, 1980).

The principality of being and effects of its rules on epistemology has made epistemology a united truth, however gradation one, which consists of different stages. And then, every 
existence, in accordance with its share in being, would enjoy epistemology too, and their developments in itself would also be their developments in epistemology. Due to this fact, objective and subjective beings are stages of a truth which are contrasted in ranks but not in the being. These epistemological stages on the being world, despite their differences, are indications of one truth, namely unity of being. According to the principle of substantial motion, human immaterial soul, which is essential mobilis, could be manifested in difference stages and ranks as self-vegetable, self-animal, practical and theoretical reasons. The soul would get a new actuality in different stages by moving through itself and defecting in the truth of soul, which is why epistemology of Sadra mostly emphasizes the unity of knowledge(Alam Alhoda, 2005, p. 220).Thus the truth of human as well as his educational truth is unity but gradation. which keeps unity but includes multiples such as strength and weakness, perfect and imperfect, priority and posteriority and these multiples would be extended to all educational elements.

\section{Epistemology}

Epistemology is the large and important branch of philosophy, which treats questions in the theory of knowledge (Noddings, 2007, p. 107). The questions about possibility, quiddity, resource, realm, and the tools of knowledge proposed in this field (Sajjadi, 1997, pp. 79-85).Discussions on knowledge in Transcendental wisdom are branched off in two major parts: the first discusses the ontological rules of knowledge and the second proposes the realization for the world, so Sadra-ee Epistemology is contributed to, influenced by and affects the intellectual, mystical discussions and religious doctrines, which distinguishes Sadra-ee Epistemology from others. Three basic components of Sadra-ee epistemology are: a) scientific ideas or the substantial known object, b) the knower or the soul, and c) reciprocal relations and proportions which the scientific ideas attain in the process of knowledge (Alizadeh, 2004, p. 29), and it is indicating the being and its rules entering the knowledge realm. In the present paper, the ontology of knowledge is offered, then its epistemology in Sadra philosophy.

Knowledge varies in Islamic wises' viewpoints; some of them account it in the category of quality of soul, some others in the category of relation, and others in the category of passivity (Dehbashi, 2007, pp. 303-6). Mulla Sadra believes the knowledge is out of quiddities the same as being and defines it as some mode of the being, so he believes it self-explanatory such as the being and self-sufficient of definition and limitation (Ashtyani, 1981, pp. 98-101). Thus, from Sadra's viewpoint, the truth of knowledge is a being abstracted from matter, which is achieved in one of three ranks of sensory, imaginary, and intellectual, and united with the soul i.e. substantial and perceived in any rank of knowledge and perception. So, in discussing ontologically on the knowledge, we deal with this question whether knowledge is of being or quiddity, of substance or accident, immaterial or material and the types and essentials of knowledge.

Substantiality and immateriality knowledge: after expressing and rejecting the meaning and interpretation of other Islamic wises from the knowledge, Mulla Sadra returns it to the 
truth of being (Ebrahimi Dinani, 2004, p. 99). Thus, Sadra holds the truth of knowledge self-explanatory, the most known the other things and indefinable, and doesn't consider it as substantial and accidents (Sabzevari, 2008, vol. 1, p. 818). Thus, the knowledge is of the being and it means exploration of the known object for the knower and its apparentness corresponds with the being temperament. In Sadra's word, to be a known object is something from which to be existence isn't separable at all, indeed, this existence is of perceptional one which isn't limited to the material world (Mulla Sadra, 1981).

Immaterial of knowledge: Also, he disclaims the notion of whoever considers the knowledge as matter and denies any imperceptible and immaterial perception and knowledge. And, he believes the immaterial of knowledge and holds the perceptibles and material world the means to achieve knowledge.

Knowledge divisions: In Transcendental wisdom, the knowledge is divided sometimes based on the being hierarchy, and sometimes based on how to be realized for the world. In interpretation on Kafi Principles, Mulla Sadra parts the knowledge into transaction knowledge and revelation knowledge and also in the Asfar he divides it such as ignorance into the simple knowledge and composite knowledge. His descriptions and justifications about all his categorization is that he believes the theoretical knowledge and reason take priority to the practical knowledge and reason and hence he confirms Ghazali's view, that is, reason is the governor who never would be deposed (Ebrahimi Dinani, 1996, pp. 322-336).

Knowledge essential elements: Of the first affairs on which the realization of knowledge entails are the known object, the knowledge, and the knower (Javadi Amoli, 1993, p. 107). In Sadra epistemology, the knower or the soul has a role beyond the pure passivity. The theory of transcendental knowledge and its perfectionary course in triple worlds, sensational, imaginational, and intellectual worlds show that the soul has in some stages the acceptive role of forms and by passing the higher stages and by transcendence of existence, it finds a creative role and turns into the creator of scientific forms or in well-known words, subsistence of issuing. In fact, to Sadra, the soul is an affair which is the origin the various and dissimilar impressions in thing (Mesbah Yazdi, 1998, vol. 1, pp. 58 \& 133). He also expresses the scared faculty like Avicenna (Ibn-Sina) which is hidden to the ordinary people and apparent to the prophets and powerful faculty of souls. Mulla Sadra differs from the other Islamic wises in the soul powers "The soul in its oneness is the whole faculties" (Mulla Sadra, 2009 , fourth journey, first book, pp. 58-9) and in justifying it based on the gradation rule. The known object is the other pillar of the knowledge and is the opposite point of the unknown object. The known object is either in the form of the known form or the known genuine (Nasri, 2006, pp. 326-32). If the known object has an external origin, it will be manifested in mind form, and if it is made by the mind and without an external origin, it will be manifested in genuine idea which in turn is the criterion for dividing the knowledge into the knowledge by acquisition and the knowledge by presence. Mulla Sadra believes the reality of knowledge is nothing but the existence, expressing that the knowledge is the existence, but not any existence rather an actual and not potential existence, but not any actual existence rather a pure actual existence which is not mixed with inexistence (Mulla Sadra, 2009, fourth journey, book 2, pp. 91-99). 
Knowledge possibility: all Islamic philosophers confirmed and endorsed the ability to achieve the knowledge by human; maybe the best reason for the possibility of knowledge is its occurrence in the external world (Beheshti, 2006, p. 106). And thus, the main axis and central core of epistemological issues focus on the answers to the question of the possibility of knowledge by human (Mesbah Yazdi, 1998, vol.1, pp. 146-7).

Knowledge resources: Mulla Sadra corresponds the stages for the realization of the knowledge with the three worlds of existence, that is, sensational, imaginational, and intellectual worlds. So, the origins for acquiring knowledge by the soul would become the source of knowledge.

Knowledge realm: in the discussion on the realm of knowledge where it is defined what realities are distinguishable for human and what are not, he splits up the knowledge in two realms, and to do that he applies the same criterion used in categorizing the knowledge into knowledge by presence and knowledge by acquisition. Thus, in Sadra's viewpoint, the realm for the knowledge by acquisition is finite, but the one for knowledge by presence is infinite.

Knowledge faculties: Islamic wises such as Ghazali (Ebrahimi Dinani, 1996), Ibn-Sina (Avicenna) (Saadat Mostafavi, 2008), Khaje Nasir Toosi (Ebrahimi Dinani, 2007), believe the knowledge acquisition powers in human, also Sadra does too (Beheshti, 2006:p. 107). These faculties are shown in the following table.

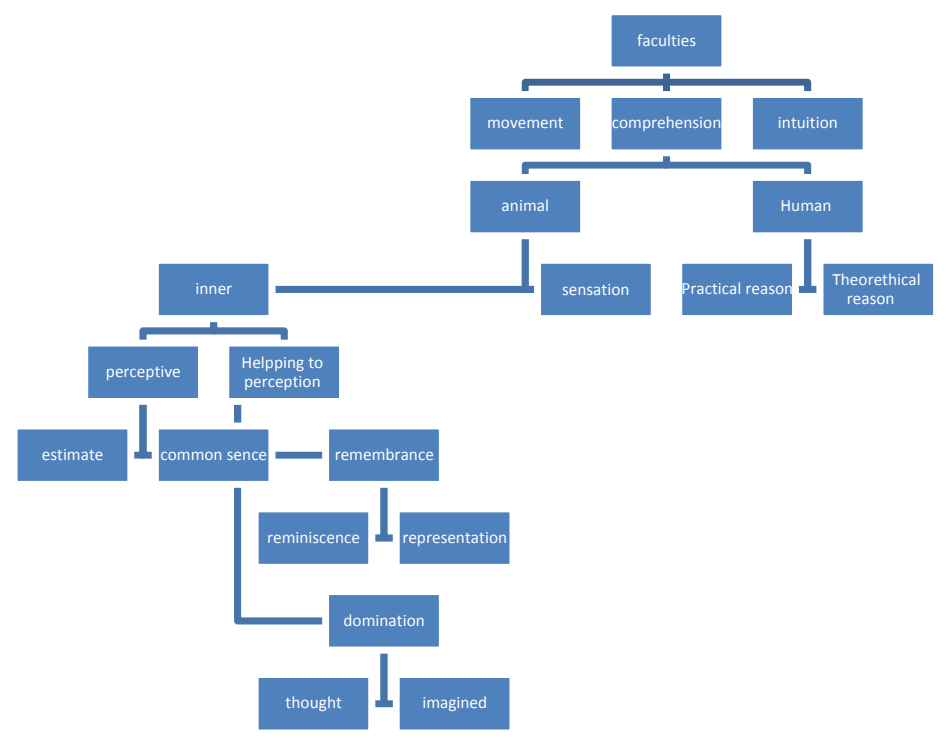

Figure 1.

Knowledge criteria: the debate on the criterion and the value of knowledge was started when in some cases of his knowledge, the human realized some mistakes in some of his thoughts. In his book, the Asfar (Mulla Sadra, 2009, first journey, book 3, pp. 244-50; third journey, book 1, pp. 16-17), Sadra disapproves in his various expressions the knowledge and conception which isn't correspondent to the reality, and calls it ignorance. To Islamic wises, object in itself is the very reality (Mesbah Yazdi, 1998, vol. 1, p. 254), and in Sadra's word, the essence of anything must be found based on itself, i.e., because the propositions are 
applied to transfer the knowledge, as if they are a meaning of reality and the reality of any proposition is justified based on the very proposition, since in the logic, the propositions have been categorized into mind, external or real propositions (Mulla Sadra, 1981, p. 59). So, the object in itself of any knowledge must be measured by its relevant proposition, and it is the very meaning "Demonstration of any object is necessary for that own object", which is of very important rules in Islamic philosophy (Ebrahimi Dinani, 2009b, vol.1, p. 56). An important point which is proposed in the discussion on the criterion and the value of knowledge in Transcendental wisdom is endless correspondence of object and mind, that is, the correspondence of mind with its object is resulted from the objective correspondence of the being beyond the quiddity with its special being, in simpler words, the correspondence theory in Transcendental wisdom returns to the discussion on commensurable and correspondent levels of existence, which is proposed in longitudinal correspondence of knowledge.

\section{Epistemology Foundations}

In Arabic language, the word Mabna (foundation) and its plural Mabani (foundations) are derived from the root Bana (basis), and its original meaning is integrating the components and special elements to create special body, either material or immaterial, with special qualities. In previous analyses on the epistemology, it was stated that the foundations of Sadra epistemological are discussed in two realms of ontology and epistemology and most of them are resulted from the being and its rules entering the knowledge in Transcendent wisdom and are justified by two basic principles of Sadra-ee wisdom, that is, primacy of being and substantial motion. Considering above discussion on epistemology in transcendental wisdom, the epistemological fundamentals can be listed in terms of being and knowledge as follows:

- Knowledge being identical with existence, whose consequence is abstraction of various concepts from one example, i.e. knowledge, although these concepts are various and different, but they are one object by existence i.e. knowledge.

- Reasonable soul is all faculties, in transcendental wisdom word: "The soul by itself is the whole faculties".

- The soul is temporality corporeal and survival spirituality that indicating on perfecting soul.

- Ideas subsistence in the soul is issuing not inhering that indicating creative human reasonable soul.

- In its gradual conduct and existential perfecting, the object adds actuality to actuality, intensifies its being and moves towards the perceptual being.

- The intelligent, the intelligible, and the intellect or the knower, the known object, and the knowledge are united in each other, and in such unity, an existence is put as example for several intellect and quiddity conceptions. 
- The perceptible world is counterbalanced by the intelligible world in transcendental wisdom.

- The theoretical reason takes priority to the practical reason, and each of them has levels and degrees.

- There are basic differences between the substantive known object and the accidental known object, and it results in two knowledge by acquisition and knowledge by presence.

- There is possibility of knowledge for man.

- Peoples differ in knowledge levels.

- Human can not attain knowledge about all affairs, so needs an external argument, that is, the prophet.

- The knowledge has hierarchy.

- The criterion of real knowledge is its longitudinal correspondence.

- The extreme knowledge is the knowledge to the origin and the end.

\section{Epistemology and Education}

Human is defined by any philosophical, intellectual, and religious school based on its fundamental principles. Also, Human is defined in transcendental wisdom according to its principles. In Sadra epistemology, human is an existence left between the heavenly and earthly worlds, and, intellectual and sensual forces (Mulla Sadra, 1981). In this view, the human is mixed with goodness and badness and his goodness aspect is attributed to his soul and his badness to his lust, and none of these two aspects have any priority over the other. Addressing to the verse 22 of the surah Zomar "Is he whose bosom Allah hath expanded for the Surrender, so that he followeth a light from His Lord, Then woe unto those whose hearts are hardened against remembrance of Allah. Such are in plain error.", Mulla Sadra believes, the peoples' soul and intellect differ from each other in terms of pleasantness and murkiness and perceiving the facts, respectively (Nasr, 2002; Mulla Sadra, 2004, vol. 2), and the most preeminent soul and intellect are settled in the most moderate and reasonable bodies and the lowest soul and intellect in the most immoderate and irrational bodies. Mulla sadra states the position of human so high and believes that the whole cosmos has been created for him and he is the most heaven argument and proof for the creatures and he is his Caliph on the earth. So, Sadra indicates in his book Mafatih al-qayb (Mulla Sadra, 1984) that the utmost goal of the creation of human is to worship God, addressing to the verse 56 of surah Zaryat " $I$ created the jinn and mankind only that they might worship Me.". Sadra states, God orders the humankind to worship him to accede to the felicity and it is achieved by observing God through annihilating the human's essence. Sadra describes the purpose of creation of human to reach the inferred reason, i.e. to observe the reasonables and to connect to the supreme heavenly court (Mulla Sadra, 2010, p. 207). Sadra resolves the disagreements between the 
justification, mysticism, and Quran by the aid of epistemological principles. Education finds its special meaning in Sadra's epistemology, so firstly and before entering this discussion, the epistemology and education is investigated in several important schools of philosophy, then the meaning and the concept of education is discussed based on Sadra epistemological foundations.

Tarbiat (education): It is an Arabic word. Arabic dictionary shows that this word can be derived from two roots i.e. Rabava or Rababa. The first means abundance and the second the possessor, creator, and instructor (Bagheri, 1991, pp. 4-46; Beheshti, 2008, p. 31). Considering these two roots, they share several aspects, but basic differences are seen between them, resulting in different definitions and interpretations from the word Tarbiat (education). So, the value of education is that manhood of humans depends on his education, in Kant's word, human can attain manhood by education and human is nothing but what the education makes (Kant, 1983, p. 42). In Sadra epistemology, human has the first and second innate dispositions, and the second innate disposition achieved by acquiring perfectnesses of soul; also Kant has stated education one of two difficult innovations (ibid, 8), in other words, addressing the Sadra's word which is indicating that both education and educator is the human, so the discussion on education in Islam aims at making human (Motahari, 1999, p. 1).

Idealism epistemology and education: idealism epistemology holds the mind of human eloquent but limited in that of perfection and eloquence is trying to be integrated with the absolute mind (Gutek, 2001; Shariatmadari, 1998), and human can observe inside himself through intuition, insight, and clear-sightedness and find a version of absolute in it. So, the challenge of education is to bring knowledge to the well-informed conscience. It is in such education that hidden and potential talents are planned and the learning will be exploratory process through which the learner is promoted to recall the story in his mind.

Realism epistemology and education: realism epistemology, contrary to idealism epistemology, accepts the objective system of realities, supposing the world of objectivities independent of subjectivities (Naghibzadeh, 1997; Shariatmadari, 1998), where the objects are independent and prior to mental experience and the knowledge for such realities guides the human to the knowledge of quiddity of objects. thus in this view, human knowledge necessitates the interaction of mind and object, in which sensory system of human involves, so the senses are the knowledge initiators but not its extremity. In other words, the knowledge implies sensory perceptions and intellectual abstraction, thus categorization finds an especial place in realism epistemology and such categorization results in a shared essence or nature in all people in a social class (Gotek, 2001, pp. 59-60).

Thomism epistemology and education: other important epistemology is that of Thomism as a God-believing viewpoint (Gilson, 2005). Thomism epistemology follows Aristotlic basic models, i.e., it considers the sensory experiment as the necessary stipulation and according to it, the mind engages in conceptualizing through the process of abstraction and categorization the properties and qualities in the objects. Also, in this view, the most excellent activity by human is reasoning (conceptualization), but it is considered incomplete happiness. This viewpoint emphasizes also the physical, social, and ethical education and the real happiness 
is achieved through the aid of divine ascent and immediately emotional and cognitive unity with God.

\section{Epistemology and Education Elements}

Considering three abovementioned viewpoints serves as an entrance into Sadra epistemology and education based on it, and the important influences which the epistemological foundations has on education. How foundations of Sadra-ee epistemology and the educational elements based on it interact and how they demonstrate a perspective of the education is discussed bellow.

Education with any accepted concept, definition, and viewpoint has four elements in education philosophy: a) curriculum, b) method of teaching, c) teacher, and d) student (ibid, pp. 7-11). To this reason, these four elements are studied in Sadra epistemology system.

Curriculum: The more challenging element in epistemology of education is curriculum. In other fields, the curriculum is discussed in terms of teaching and its goals, content, methods, tools, and evaluation. But, in the field of epistemology, their reality is explored. The curriculum has been described variously through the history of education, but in common language, the curriculum is an organized experience which the learner acquires under guiding and supervising the school (Gutek, 2001, p. 12). So far, four groups of curriculum theories have been specified (Decker, 2003, pp. 62-65). First, the theories dealing with intellectualizing the curriculum. Plato, Locke, Pestalozzi, Herbart, Spencer are in this group. Second, the theories dealing with intellectualizing the steps of creating or determining the curriculum rather than expressing its logic. People such as Babbitt and Tyler belong to this group. Third, the theories conceptualizing the phenomena of curriculum and having less relationship with scientific activities to formulate the curriculums. The impressing person in this group is John Dewey. Fourth, theories determining the phenomenon of curriculum with their powerful theoretical aspects, it is obvious that the first three groups of theory seek to improve the curriculum, and the fourth tries to find a deeper perception about the curriculum and leaves its application for others.

Analysis of the foundations of epistemology and ontology show that planning and delivering the curriculum should possess some attributes, resulting from such foundations. Some possible attributes of such curriculum is discussed bellow.

Goal: Any creature has perfection which is meant by its creation, that is, the goal of its education is to reach the perfection (Shokuhi, 1994, p. 37). Offering several definitions about knowledge, Mulla Sadra states his definition about the knowledge in the Asfar (2009, first journey, book 1, pp. 21-24): "wisdom means seeking to be similar to the heaven in embracing the generalities and abstracting from materials", that, one of them is the last degree of knowledge and the other is the most excellent stage of action. In the book titled the origin and resurrection (Mulla Sadra, 1982, pp. 417-430), it was stated that the perfection and happiness of anything is to reach something which fits best its innate.

So, the main goal of education is the perfection of scientific power, ie., perceiving the generalities through which the knowledge to God, prophets and Last day is achieved, and the 
perfection of practical reason finds its meaning under the auspices of the theoretical reason, that is, to Mulla Sadra, the perfection of the practical reason is not the truth happiness, to him, the purification of the soul isn't the perfection because it is nothing and the nothings isn't accounted the perfection (Mulla Sadra, 2010, pp. 365-69). In education based on this main goal of Sadra epistemology, several goals are found, out of which some are addressed in the following in brief.

Preparing grounds and circumstances: Sadra takes into account five elements as the barriers to exploration of scientific expressions and in fact, the barriers to evolution of human to existence levels (1982, pp. 425-29), which are: 1) defectness of the soul essence such as a baby's soul, that is, the soul in which the intelligibles forms are not theophanied, 2) impurity of the soul essence and its darkness of passions and accumulation of sins on the reasonable soul preventing the purity of heart and its shininess, 3) deviating from the desired truth, i.e., they haven't reflected on the heaven, divinity, and secret and hidden realities, 4) veil, and it is a belief which the mind overtakes and is resulted from imitation and trust, and 5) ignorance, resulted from awareness of real favorite. Mulla Sadra believes the soul has the qualification to attain knowledge to the real objects, but he mentions five barriers above for human to achieve the knowledge to the realities of objects. It is revealed from the barriers to the perfecting of the soul and in fact to the journey to the educability of human that to create circumstances, there must be attributes such as being proportionate to the level of existence and knowledge of the person, avoiding from imposing beliefs, keeping in mind that the corporeal movements and habits and behaviors of body members can prevent from reflection and contemplation, and the learnt objects and issues can serve as veil, so grounds and circumstances to teach and to learn in education based on Sadra epistemology can not emphasize only developing the accidental sciences, even can not be halted in the course of longitudinal perfecting.

Enhancing the intellectual thinking and developing the revelation and intuition based on it (Yasrebi, 2008, p. 303): other educational goal is thinking based on the foundations of Sadra epistemology. Since the talking soul of human is intensified by attaining knowledge to the reality of every thing and to the identity of every existence and this becoming is achieved through internal thinking, i.e., the knowledge by presence, although the knowledge by acquisition serves this becoming as a tool, so the Sadra-ee educational environment must be so that the learners can transform their theoretical reason to reason gradually and achieve the revelation and intuition through intellectual thinking.

Knowledge to the soul and its existential areas and levels: in Sadra epistemology, the knowledge to soul is the prerequisite of the knowledge to God. To Sadra, the knowledge to soul is so important that he has mentioned it as the first principle of his three principles (Nasr, 2002, p. 15), of which the ignorance results in frustration and abortiveness in the Last day. Therefore, when the learners attain knowledge to their soul and its levels in Sadra educational environment, they can attain the knowledge to God with more tranquility and more easiness.

Purposefulness: the final purpose of this curriculum should be to become similar to the heaven and to be annihilated for him. Thus, the educational experiences, opportunities, and 
situations must be so that to accomplish this extremity. But, in Sadra epistemology, peoples but not the prophets can not accomplish it without passing the hierarchy of three sensory, imaginary, and intellectual worlds. Therefore, the curriculum must be designed as a hierarchy from sensory world, to imaginary world, and to intellectual world, and all of these goals must be in the service of heavenly goal.

Flexibility: Transcendental wisdom considers the human the only existence whose perfection is posterior from his existence, so the curriculum must be designed so that first the learners don't stop in a stage and second if developed curriculum doesn't meet their needs to perfecting, it can be the flexibility to be changed, and improved. Another reason for the flexibility of curriculum based on Sadra epistemology is that if the curriculum is rigid and constant, it will not fit the spirit of Transcendental wisdom and because people are not identical in essence, the rigid and constant experiences and situations prevent them from intellectual goals and cause teacher to stop in an existential stage and mode.

Observe the Individual differences while with keeping promoting individuality: Individuality of each person is enhanced in the transcendental wisdom distinctly from others and enhancing the capacity within each person prevents him from annihilation in relationships with others. So, the curriculum should provide different grounds, positions, and experiences while observing the humanitarian differences in different people to be able to be intensified and approach the true perfection according to their differences and limitations.

Principality of the intellectual and spiritual dimensions: In his works, Mulla Sadra puts special emphasis on the intellect, to the extent which calls his great work four journeys of intellect. To be intellectual and its principality in the curriculum means that becoming intellect has different levels and stages, therefore the curriculum should be designed and planned based on such levels and stages until the learner can move step by step and slowly from the weakness and decline to intensification and perfection, so in such curriculum, rapid mutations of existential perfection have no meaning, the principality of intellect in the curriculum will be the origin of knowledge to the soul and its enhancement and also result in individuals' self-discovery and independence that in turn leads them to get rid of imitation and prejudice.

\section{Teacher}

Different intellectual schools consider special position, role and expectations for teacher, regarding to their own assumptions. Also based on the reasoning and argumentations in his works "interpretation on Kafi principles", "virtue of knowledge" and "proof", Mulla Sadra has described some narrations and dealt with discussions on the knowledge, the knower, and the learner, stating that the supreme knowledge is the knowledge to God, angels and His messengers, and the sciences leading to such knowledge, he calls it the knowledge to the soul. the learner and the teacher are measured and assessed in the light of such view; accordingly the real teacher are who moves along the real sciences and there are other teachers who are engaged in teaching sciences which are of actions, as stated before, to Mulla Sadra, the 
actions aren't real perfection, therefore, based on Sadra epistemology, the teachers are also dominated by hierarchy, the teachers engaged in perceptible issues and the teacher engaged in generalities, and at the head of teachers are the prophets. In interpretation on kafi principle (2007, vol.2, pp. 126-31), Mulla Sadra states, the real teacher has thee features: science, meekness, humility. His science is illuminated by the heavenly light, his meekness inhibits injudiciousness and light-mindedness, and his humility offers the silence unless its necessary to speak. To Sadra, teachers have some duties toward students, such as compassion, obedience the religious law, speaking to students' understanding, reminding students their evil moralities indirectly and acting as his science. It is seen that in Sadra epistemology, teacher provides circumstances and opportunities which will reduce or eliminate educational barriers and the perceptual and cognitive existence of learners is intensified and enhanced.

\section{Student}

Sadra epistemology divides the learners into two groups: the first group seeking the real sciences or self-consistent and hereafter desired goals, who can be called reality students that transcending in knowledge ascendent route to achieve true happiness, and the second group seeking the worldly sciences who are in turn divided into two groups: the seekers of the world and followers of the rulers in one hand, and the seekers of the positions and people's approval and satisfaction, on the other hand, although they call people for the Last day. So, the learner in Sadra educational environment has some duties of which it can address to purifying the soul off the wicked moralities, reducing the dependency on the world and its entertainment, entrusting tasks to the teacher, showing the modesty and humility and service to the teacher apparently and believing him heartily, not neglecting to attain the good and desired science. Of course, of important attributes of the learner in Sadra epistemology is inquisitory, because to Sadra, the key to knowledge is inquisitory and this attribute must be present in all levels of existence and never be stopped, thereby the individuals are always seeking the truth and perfection and are approaching to the real happiness, i.e., exploring the divine world.

\section{Teaching Methods}

In different books on teaching methods and techniques, the different teaching methods are presented (Joyce \& Weil, 2002; Shabani, 2002; Khorshidi, 2002). One point is mentioned here that the teaching method is indeed a hierarchical system by which the teacher applies the educational factors to influence the learners in order to create some changes or results in them. The discussion on the reality of teaching methods, and the relation between teacher, and learners, factors, circumstances, and the resources for teaching and learning is complicated in Sadra-ee epistemology, because the methods based on these foundations should emphasize inquisitory, seeking the reality and the perfection, and intensification of teacher and student, and these factors should have the argumentative, mystical and Quranic coherence. In other words, the teaching methods adapted from Sadra epistemology should involve the 
philosophical and mystical methods, using Quran and Sunna. In Sadra epistemology, the reality of the world of possibilities and beyond Allah is achievable and perceptible, but the being necessary being in his essence, that is, the essence of God can not be perceived by such methods but by mystical methods, ie., by contemplation and discernment, and these two methods are real when they are in accordance with Quran and sunna. The methods for relationship between teacher, learner, and factors of educational environment, or in other words, teaching methods are integrative. Therefore in Sadra-ee epistemology, the philosophical methods are enough for attaining knowledge to the soul and the intensification of the existence, but to visit God, the mystical methods are achieved through Quran and Sunna, it is why Mulla Sadra knows the mystic as the knower and not the knower as the mystic. It is considered that in Sadra epistemology, the teaching methods aren't markedly different, because all of them must be in accordance with the utmost goal of education that is nearness and likeness to God. It is the richness of the content of curriculum that can provide such circumstances for the teaching methods to be executed in the transcendental wisdom.

\section{Perspective of Education Based on Sadra Epistemology}

The transcendental wisdom is based on three pillars of argumentation, mysticism and the Quran. Entering the discussion of knowledge through the discussion of existence results in these three pillars to be proposed in the epistemology of this wisdom. Its educational perspective is based on the three pillars above, and it is not so that each of them denies the other, rather the integration of them, which has gained in enough coherence in an longitudinal course. Mulla Sadra calls in somewhere the education as scientific conduct in accordance with existential conduct and or turning potentiality into actuality, in other work, he calls the education as being taught for intellectual manners, divine services, real sciences and convictions (Mulla Sadra, 2004, vol.1, p. 121). In education based on Sadra-ee epistemology, it is impossible to perceive the reality of objects only through teaching, learning, and reasoning, or the very knowledge by acquisition without exploration, intuition, imagination and conscience based on divine education; to Sadra, the final goal of education is to attain the intuition of The Lord and to be annihilated for him, and it makes human free from complete ungratefulness to be educated the knowledge by acquisition, but not completely, and the knowledge by acquisition is of tools and instruments of which the learner makes use to achieve the higher levels of existence, and it is because of this, that in transcendental wisdom, it is necessary to be educated and learn natural sciences, mathematics, and philosophy and only the direct exploration and intuition belongs to the prophets and the complete manifestation of it can be seen in the last prophet Mohammad (PBUH) and the other people have no competency for it (ibid, 2004, pp. 77-80).

Educational perspective based on Sadra-ee epistemology has various and complicated dimensions just as the transcendental wisdom, but, what is always happened in the wisdom is the emphasis on intellectual journey, in simpler words, priority of theoretical reason over practical reason, therefore all educational elements such as goals, curriculum, teacher, learner, and teaching methods should be in this direction and for reaching this goal. Curriculum is 
such a program in which the corporeal, social, moral, intellectual, and Quranic education are considered coherent and real so that it meets the longitudinal conformity, thus sensory and natural sciences serve the imaginative sciences, and they in turn serve intellectual sciences, and they also are in service of divine sciences. In other words, sciences in curriculum based on Sadra-ee epistemology are of hierarchy, and at the bottom is the sensory sciences and on the top the divine sciences, that is, the very knowledge to the origin and resurrection and being annihilated for God. That curriculum is not confined to experimental and intellectual aspects, but they should pave the road to the intuition and exploration of divine sciences in a field of imagination and internal deportment. Such purposeful and flexible curriculum considers the individual differences, preserves and enhances the individual existence and the principality of intellect in a whole coherent entirety.

In educational perspective of Sadra-ee epistemology, the teacher is a person who steps in the direction of the real sciences that is, sciences which is nobler than the other sciences in terms of both subject, and reason and fruit, and isn't satisfied only with teaching sciences of actions or professions. Recognizing his soul and perfecting his existence, such a teacher promotes the learner to reflect and stimulates seeking independency in thinking, and avoids from any type of intruding the ideas or providing such an intruding educational environment, and thus turns learning and external acquisition into contemplation and discernment in order to enhance his real knowledge and not to be only a reservoir of words and expressions.

Learner, in educational perspective, is an inquisitor and is always seeking the reality of everything and reveals such reality through knowledge and sciences to himself and enhance his intensification and perfection. In such perspective, learner doesn't add quantity to quantity, but perceives and explores continuously his hidden talents and existential abilities and actualizes them. Such a learner is always a very diligent critic with no fear, because he considers the criticism as a developing and perfecting phenomenon and fosters it in himself in order to gain his real happiness, i.e. exploration and intuition of divine world and the heaven and The Lord, so learner avoids from any imitation and prejudice and finds independency in thinking.

Other important element, which is considered in this educational perspective and in fact, binds the relation between teacher, learner and present factors in the educational environment and facilitates the extremities and final goals of education, is teaching method. Teaching method based on Sadra epistemological foundations is a complicated and integrated one. As stated before, the method to attain the science and knowledge in Sadra's viewpoint is a mixed up of methods of knowledge by acquisition, knowledge by presence, and Quranic method, therefore the experimental, philosophical, mystical, and religious methods are acceptable in this viewpoint, but each according to its position. In other words, the experimental methods serve philosophical methods; philosophical methods serve mystical methods, and mystical methods serve religious methods. By considering that in Sadra epistemological foundations, each actualized knowledge level is serving the higher level and the higher level has all of perfections of the lower levels. 


\section{Conclusion}

Unique characteristic of education based on Sadra-ee epistemology is the interring of existence and its judgments in the arena of knowledge, which leads to justify the reality of education by two pillars of transcendental wisdom: the primacy of being and substantial motion. In such educational system, the reality of education and its meaning and concept is interpreted and justified so that having and preserving its unity, it possesses multiplicities such as strength and weakness, priority and posteriority, superiority and inferiority, and as the educational environment enhances and evolves like a natural phenomenon without losing its concrete and unique identity, it develops in all its different stages and levels and gains a kind of multiplicity of priority and posteriority, and strength and weakness, without that such multiplicity blemishes the reality unity; so the reality of education is the basic and instructive superiority of education based on Sadra epistemology over various educational systems, existed or existing.

In perspective of the education truth, human is a creature which doesn't stop in him and makes himself by his thoughts and actions and engages in self-creating knowledge through educational elements such as goals, curriculums, teaching methods, and other educational facilities and equipments, thereby faith, which is the intellectual light, is manifested in him. In such educational environment, the individual exits from himself to become familiar with strange and unfamiliar ideas, thereby he transcends and deals with his existential and knowledge perfection, so what he assumes separate from himself, now recognizes as the own existence, it is because of this that keeping away the individual from the world of thoughts and various foreign mental spaces is not the privative aspect of this educational view, otherwise it limits and confines the educational view and perspective, which is not compatible with the reality of the transcendental wisdom.

Other important point in the education based on Sadra epistemology is that its educational elements should be always balanced, and this balance should be respected in both knowledge level and longitudinal levels of knowledge. In other words, in this educational view, education is originated from a single and unique resource, and moves toward a unique and single utmost, therefore any scatteration and non-coordination among educational elements in any position can halt the existential level of reality and make it away from the extreme happiness i.e. proximity to God, whereas the balance between the educational elements in any educational perspective can activate the possible beings of human and facilitate the progress of human from natural ego (self) to divine self. 


\section{References}

The Holy Quran.

Akbarian, Reza. (2010). Human'splace in Mulla Sadra's Transcendent Philosophy. Tehran, Elm publication.

Alizadeh, Biuk. (2004). Justification of Sadra Epistemological Theory. Journal letter of Wisdom, 3, 5029.

Ashtiani, Seyed Jalal Al Din. (1981). History and Philosophical Ideas of Mulla Sadra. Tehran, Muslim Women's Movement.

Bagheri, Khosrow. (1991). Looking Back to Islamic Education. Volume I, Tehran, Madresseh Publication.

Beheshti, Saeed. (2006). Epistemological Foundations of Islamic Education, with emphasis on Sadra Transcendent Psychology. Journal of Psychology and Educational Sciences, Serial No. 119-101.

Decker, F. Walker. (1982). Curriculum Theory is Many Things to Many People. Theory in to Practice (TIP), 3, 6265.

Dehbashi, Mahdi. (2007). Epistemology and Ontology of Sadra and Whitehead, Research, Criticism, Review and Comparison. Tehran, Elm publication.

Ebrahimi Dinani, Gholamhussein. (1996). Logic and knowledge in Ghazali's view. Tehran, Amir Kabir Publication.

----- (2004). Independent and Intermediary Existence in Islamic philosophy. Tehran, Knowledge and Philosophy Research Institute.

----- (2006). The Adventure of Philosophical Thought in Muslim World. Volume III. Tehran, Tarhe Nu.

----- (2007). Nasir AlDin Toosi, Philosopher of Talks. Tehran, Hermes publication.

----- (2009a). Radius of Thought and Intuition in Sohrevardi Philosophy. Tehran, Hekmat Publication .

----- (2009b). General Rules of Philosophy in Islamic Philosophy. Tehran, Institute of Humanities and Cultural Studies.

Gillson, Etienne. (2005). Le Thomisme: Introduction á la Philosophie de Saint Thomas d' Aquin (Seyyed Zia Dehshiri, Trans.). Tehran, Hekmat Publication. (original work published 1989).

Gutek, Gerald. (2001). Philosophical and Ideological Perspectives in Educational ( Mohammad Jafar Pakseresht, Trans.). Tehran, Samt.

Hakkak, Seyed Mohammad. (2006). Logic, Criteria of Thinking. Tehran, Samt.

Izutsu, Toshihico. (1980). The Basic S structure Metaphisics Sabzevari(Seyed Jalal AlDin Mojtabavi, Trans.).Tehran Branch of Institute of Islamic Studies in University of 
MacGill and Tehran University Tehran.

Javadi Amoli, Abdullah. (1993). the Knowledge in Quran. Qom, Raja Center of Cultural Publication.

Joyce, Bruce., \& Weil, Marsha. (2002). Models of Teaching (Mohammed Reza Behrangi, Trans.). Tehran, Kamale Tarbiat Publication.

Kant, Immanuel. (1983). The Education (Gholamhussein Shokoohi, Trans.). Tehran, Tehran University Press.

Khamenei, Seyed Mohammad. (2004). Transcendental Wisdom and Mulla Sadra. Tehran, Institute of Sadra Islamic Philosophy Publication.

Khandan, Ali Asghar. (2005). Applied Logic. Tehran, Samt, Cultural Institute of Taha.

Khorshidi, Abbass. (2002). Methods and Techniques of Teaching. Tehran, Yastoroon Publication.

Mesbah Yazdi, Mohammed Taghi. (1998). Instructing Philosophy. Tehran, Islamic Propaganda Organization.

Motahari, Mortaza. (1998). Education in Islam. Tehran, AlZahra Publication.

Mulla Sadra, Mohammed Ibn Ibrahim. (1981). Asrar alAyat (Mohammad Khajavi, Trans.). Tehran, Institute for Cultural Research and Studies.

----- (1981). AlManteq_e Nu (Abdul Mohsen Meshkat AlDini, Trans.). Tehran, Agah Publication.

----- (1983). AlMabda Wa Al Maadd (Ahmad Husseini Ardekani, Trans.). Tehran, University publication.

------ (1984). Mafatih AlGayb (Mohammad Khajavi, Trans. ). Tehran, Mola Publication.

(2002). Resaleh se Asl (Investigated and corrected by Seyed Hussein Nasr).Tehran, Institute of Sadra Islamic Philosophy Publication.

----- (2004). Sharh_e Usul alKafi (Mohammad Khajavi, Trans.). Vols. 1 \& 2. Tehran, Mola Publication.

------ (2007). AlMazahir (Seyed Jalal AlDin Ashtiani,Trans.). Qom, Institute of Bustan Ketab.

(2009). AlHikmat AlMuta'aliyah fi'lAsfar AlArba'ah (Mohammad Khajavi, Trans.). The first journey, First book. Tehran, Mola Publication.

----- (2009). AlHikmat AlMuta'aliyah fi'lAsfar AlArba'ah (Mohammad Khajavi, Trans.). The third journey, First book.Tehran, Mola Publication.

----- (2009). AlHikmat AlMuta'aliyah fi'lAsfar AlArba'ah (Mohammad Khajavi, Trans.). The first journey, Third book. Tehran, Mola Publication.

(2009). AlHikmat AlMuta'aliyah fi'lAsfar AlArba'ah (Mohammad Khajavi, Trans.). The fourth journey, First book. Tehran, Mola Publication. 
(2009). AlHikmat AlMuta'aliyah fi'lAsfar AlArba'ah (Mohammad Khajavi, Trans.) . The fourth journey, Second book. Tehran, Mola Publication.

----- (2010). AlShawadhid AlRububiyyah fi AlMenhaj AlSolukiah (Javad Mossleh, Trans.).Tehran, Soroush publication.

Naghib Zadeh, Mir Abdul Hussein. (1997). A Glance at Philosophy of Education. Tehran, Tahoori library.

Nasr, Seyyed Hussein. (2002). Knowledge and Spirituality (Ensha Allah Rahmati, Trans.). Tehran, Suhrawardi Centre for Research and Publication and International Centre for Dialogue of Civilizations.

Nasri, Abdullah. (1992). Perfect man of Schools' Viewpoints .Tehran, University of Allameh Tabatabaei.

Nasri, Abdullah. (2006). Analytic Philosophy and Theory of knowledge in Islamic Philosophy. Tehran, Elm publication.

Noddings, Nel. (2007). Philosophy of Education. Published by Westview Press.

Saadat Mostafavi, Seyed Hassan. (2008). Description of References and Disciplines (Third mode), About the Soul. Tehran, University of Imam Sadegh (PBUH).

Sabzevari, Haadi. (2008). Descriptions Lessens of Mulla haadi Sabzevari ordered (Description by Yahya Ansari Shirazi). Vol . I: "Logic". Qom, Bustan Ketab,

Sadjadi, Seyed Mahdi. (1997). Survey on Epistemological Wiews of Philosophical Schools (Idealism, Realism, and Pragmatism), and Its Methodological Implications in Education Philosophy. Journal of Educational Researches, 1 \& 2, 77-101.

Shaabani, Hssan. (1997). Instructional Skills: Teaching Methods and Techniques. Tehran, Samt.

Shariatmadari, Ali. (1998). Philosophy: Philosophical Issues, Philosophical Schools and Foundationt of sciences. Tehran, Office of Culture and Islamic Press.

Shokuhi, Gholamhussein. (1994). Education and Its Stages. Mashhad, Astan Quds Razavi.

Yasrebi, Seyed Yahya. (2008). Theoretical Mystic. Qom, Bustan Keta Publication.

\section{Copyright Disclaimer}

Copyright reserved by the author(s).

This article is an open-access article distributed under the terms and conditions of the Creative Commons Attribution license (http://creativecommons.org/licenses/by/3.0/). 